\title{
RELATĪVĀ BIEŽUMA VĒRTĒŠANAS METODES IZMANTOŠANA LATVIJAS PRIMĀRO EKSPORTA NOZARU ATTİSTİBAS TENDENČU PËTĪŠANĀ
}

\author{
Antons Berjoza, Juris Paiders \\ LU G̦eogrāfijas un Zemes zinātṇu fakultāte, \\ e-pasts: antons.berjoza@inbox.lv, jpaiders@inbox.lv
}

\begin{abstract}
Anotācija. Rakstā tiek aplūkotas Latvijas eksporta tendences ekonomikas pamatnozarēe lauksaimniecībā, zivsaimniecībā un mežsaimniecībā un tiek raksturoti šo nozaru svarīgākie pētījumi un pieejamā statistiskā informācija.

Autors veica eksporta geogrāfijas statistisku analīzi, izmantojot relatīvā biežuma vērtēšanas metodi un nosakot stabilākos Latvijas eksporta tirgus. Kā datu avots tika izmantota Latvijas Centrālās statistiskas pārvaldes detalizētā ārējās tirdzniecības statistika. Piegādes biežuma statistiskā būtiskuma noteikšanā tika izmantota Fišera transformācija.

Kā liecina pētījuma rezultāti, tad stabilākie Latvijas eksporta tirgi, bez Baltijas jūras reğiona valstīm, ir Nĩderlande, Norvēǵija un Lielbritānija. Darba gaitā tika identificēti statistiski būtiskie tirgi nozīmīgākajās eksporta preču grupās. Izmantotā metode l̦auj nošķirt gadījuma rakstura tirgus no stabiliem eksporta tirgiem. Atslēgas vārdi: eksports, datu analīze, piegādes biežums.
\end{abstract}

\section{Ievads}

N̦emot vērā Latvijas ǵeogrāfisko novietojumu starp Eiropas „Rietumiem” un „Austrumiem”, nav pārsteidzoši, ka ārējās tirdzniecības nozīme Latvijas ekonomikā un tautsaimniecībā ir daudzu zinātnisku pētījumu uzdevumu sarakstā. Daudzu Latvijas pētnieku - Karnupa (2004), Krišjānes (2005), Fadejevas, Meḷihova (2009), u.c. uzmanība ir pievērsta ārējās tirdzniecības jautājumiem, īpaši vērtējot Latvijas integrāciju Eiropas un globālajos tirgos. Daudzi pētījumi (Wu, Gao 2001; Haibo 2004; Peter 2008; Berentsen 2012; u.c.) apstiprina slēdzienus, ka ārējā tirdzniecība ir noteicošais faktors ekonomikas attīstībā un izaugsmē. Veicot zinātniskās literatūras izpēti, jāsecina, ka ir svarīgi novērtēt gan ǵeogrāfisko faktoru ietekmi, gan arī ārējās tirdzniecības tirgu telpiskās pārmaiņas. Viens no veidiem, kā var veikt izpēti, ir lietot analītiskas un statistiskas metodes ekonomiskās informācijas analīzē ǵeogrāfiskā griezumā.

\section{Materiāli un metodes}

Darbā tika izmantoti Centrālās statistiskas pārvaldes apkopotie dati par Latvijas eksportu harmonizētās preču aprakstīšanas un kodēšanas sistēmas 4 zīmju kodā periodā no 2000. līdz 2013. gadam. Latvijas eksporta dati par katru mēnesi tika sarindoti atbilstoši valstīm visa perioda griezumā. Šādi izveidota izejas datu matrica tika pārveidota binārā formā. Ja attiecīgajā mēnesī eksporta piegādes atbilstošā preču grupā uz konkrēto valsti notika, tad konkrētajā matricas šūnā tika norādīta vērtība 1, ja eksporta piegādes nenotika, tad konkrētajā matricas šūnā tika norādīta vērtība 0 . Rezultātā tika iegūti eksporta piegāžu biežuma rādītāji katrai preču grupas datu kopai un katrai valstij. Plašāk relatīvā biežuma vērtēšanas metodes izmantošanu ǵeogrāfiskos pētījumos ir aplūkojis Paiders (2008), bet metodes ierobežojumus - Krastiņš un Ciemiṇa 
(2003). Ģenerālās kopas biežums tika salīdzināts ar katras valsts biežumu, izmantojot Fišera transformāciju (Fisher un Yates 1963):

$$
\text { (1) } \varphi=\frac{2 \pi}{180} \arcsin (\sqrt{p})
$$

$$
\varphi \text { - Fišera funkcijas vērtība, ja } \mathrm{p} \text { ir biežums }
$$

T-statistika tika aprēḳināta, dalot Fišera funkciju (ğenerālajai kopai un attiecīgajai valstij) vērtību starpību ar brīvības pakāpju lieluma koeficientu (Krastiņš, Ciemiņa 2003). Rezultātā ir iespējams iegūt relatīvo biežumu eksportam uz jebkuru valsti, pēc kura var spriest, cik liela ir varbūtība, ka vienā uz labu laimi izvēlētā mēnesī tiks veikta eksporta piegāde uz attiecīgo valsti. Pēc t-statistikas aprēķināšanas, pieņemot, ka būtiskuma slieksnis ir ar 95\% ticamību, valstis tika iedalītas 3 grupās:

1) valstis, uz kurām Latvijas eksporta varbūtība ir statistiski būtiski augsta (ja Tempīriskais bija lielāks par 2, bet nozares vidējais eksporta piegāžu biežums bija mazāks par eksporta piegāžu vidējo biežumu attiecīgajā valstī);

2) valstis, uz kurām Latvijas eksporta varbūtība ir statistiski būtiski zema (ja Tempīriskais bija lielāks par 2, bet nozares vidējais eksporta piegāžu biežums bija lielāks par vidējo eksporta piegāžu biežumu attiecīgajā valstī, šajā grupā ir ietverami arī rezultāti, pie kuriem eksports uz attiecīgo valsti vispār nav noticis un ir vienāds ar nulli);

3) valstis, uz kurām Latvijas eksportam ir gadījuma raksturs (ja T-empīriskais bija mazāks par 2, jo šādā gadījumā, n,emot vērā darbā izvirzītos būtiskuma kritērijus, nav iespējams noraidīt nulles hipotēzi).

\section{Rezultāti un diskusija}

Pētījuma dati tika apkopoti un analizēti, salīdzinot eksporta kopējos apjomus. Katrai pozīcijai un grupai tika veidota eksporta apjoma dinamika. Var izšķirt vairākus atšķirīgus posmus, kas noteica noteiktas tendences Latvijas ekonomiskajā attīstībā.

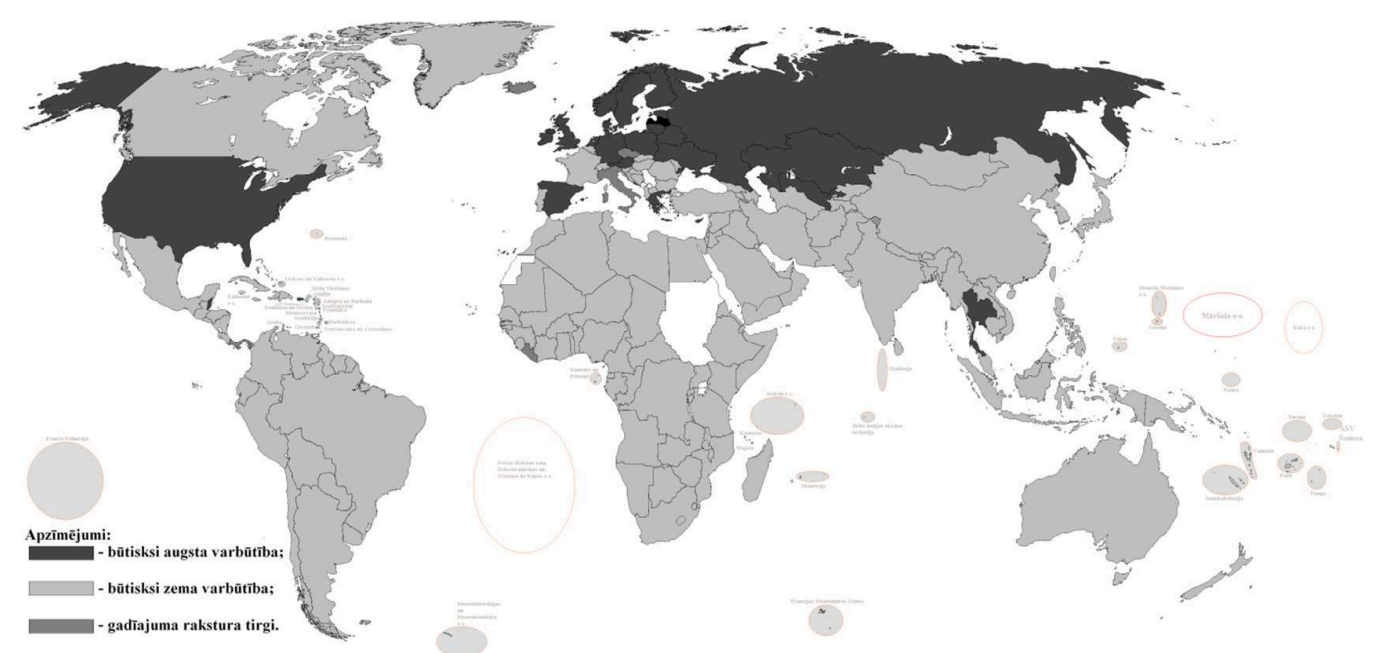

1. attēls. Latvijas graudu un to produktu eksporta tirgi pēc to stabilitātes (izstrādājis autors) 
Kā liecina iegūtie rezultāti (1. attēls), tad Latvijas graudu un to produktu eksportam stabili tirgi ir Baltijas jūras reǵiona valstīs, tuvākajās un lielākajās NVS valstīs, kā arī Latvijai tuvākajās Austrumeiropas valstīs, bet, vērtējot eksporta pārmaiṇu laika rindas un eksporta apjomu (2. attēls), lielākie eksporta tirgi ir Irāna, Irāka, Alžīìja, Ēǵipte, Lībija un citi, kas netiek identificēti kā stabilie tirgi ar relatīvā biežuma vērtēšanas metodi (1. attēls). Līdz ar to ir jāsecina, ka relatīvā biežuma vērtēšanas metodi var izmantot, pētot eksporta tirgus, kuros notiek kaut vai nelielas, bet regulāras piegādes. Savukārt, vērtējot pēc apjoma, tika uzrādīti gadījuma tirgi, uz kuriem eksporta lielums un biežums ir atkarīgs tikai no tirgus konjuktūras.

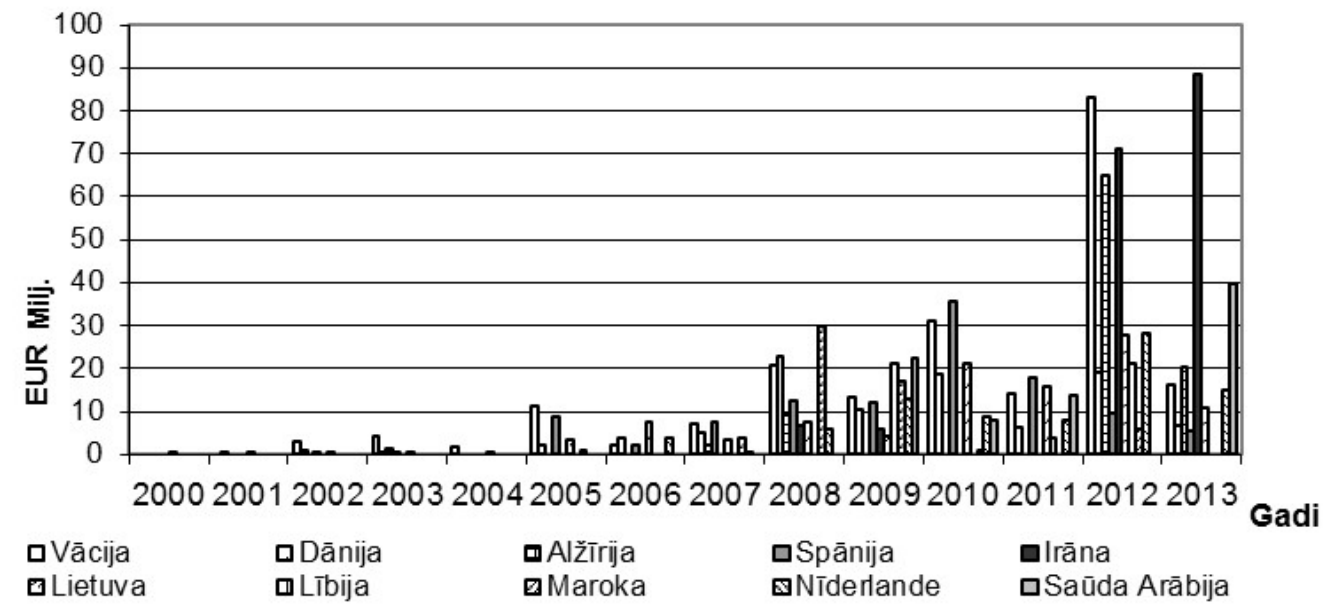

2. attēls. Latvijas graudu un to produktu eksporta dinamika 2000.-2013.g. (izstrādājis autors, izmantojot CSP datus)

Visās analizējamās produktu grupās tika novērotās līdzīgas tendences, iezīmējot gan stabilos un pastāvīgākos, gan gadījuma eksporta tirgus. Jāteic, ka daudzās preču grupās tik krasas atšķirības, kādas bija novērojamas, vērtējot graudu un to produktu eksporta ǵeogrāfiju, nav raksturīgas. Piemēram, svaiga piena eksporta ǵeogrāfija ir ḷoti ierobežota, jo produkcijas transportēšanas (eksportēšanas) attālums ir ḷoti atkarīgs no produkta derīguma termiņa, kas svaigam pienam ir tikai dažas diennaktis. Savukārt zivju konserviem derīguma termiņš ir no dažiem mēnešiem līdz pat vairākiem gadiem, kas ḷauj tos pārvadāt lielākos attālumos, kā arī uzglabāt, gaidot labāku tirgus situāciju preču realizācijai.

Latvijas eksporta ǵeogrāfijā notika ievērojams pārmaiṇas pēc Latvijas iestāšanās ES, kad notika Latvijas eksporta pieaugums gandrīz uz visām ES dalībvalstīm un eksporta samazināšanās uz valstīm ārpus ES robežām. Zīmīgas pārmaiņas Latvijas eksporta ǵeogrāfijā notika 2008., 2009. gada krīzes iespaidā, kad palielinājās stabilo eksporta tirgu nozīme. Savukārt vairākām preču grupām būtiski auga eksporta biežums uz valstīm ārpus ES, īpaši uz NVS valstīm. 


\section{Secinājumi}

Pētījuma gaitā tika pārbaudīta iespēja ekonomiskās ǵeogrāfijas pētījumos izmantot relatīvā biežuma vērtēšanas metodi, salīdzinot iegūtos rezultātus ar citām analīzes metodēm.

Relatīvā biežuma vērtēšanas metode ir izmantojama stabilo tirgu identificēšanai. Latvijas ekonomikas pamatnozarēs Latvijas stabilie eksporta tirgi ir Latvijas kaimiņvalstis - Lietuva un Igaunija, citas Baltijas jūras reǵiona valstis, kā arī Baltkrievija, Krievija, Nīderlande un Lielbritānija.

\section{Atsauces}

Berentsen, W.H. (2012). The Change in European Foreign Trade from 1960 to 2010: A Geography of Leading Merchandise Exporting Partners. Eurasian Geography \& Economics, 380-399.

Fadejeva, L., Meḷihovs, A. (2009). Latvijas Tautsaimniecības nozaru kopējās faktoru produktivitātes un faktoru izmantošanas novērtējums. Latvijas Banka: http://80.233.167.45/public_files/images/img_lb/izdevumi/latvian/citas/pet_2009-3_fadejevamelihovs.pdf (21.04.2011.)

Fisher, R.A., Yates, F. (1963). Statistical Tables form Biological, Agricultural and Medical Reserch/6th editon. London, Oliver and Boyd.

Haibo, L. (2004). Geoeconomics at Work. Beijing Review, 47(45), 3.

Karnups, V. (2004). Latvijas ārēja tirdzniecība ar Skandināvijas valstīm: Promocijas darbs. Rīga: LU Ekonomikas un vadības fakultāte, Latvijas Universitāte.

Krastiņš, O., Ciemiņa, S. (2003). Statistika. Rīga, LR Centrālā statistikas pārvalde, Krišjane, Z. (2005). Latvia: A Centre-Oriented Country in Transition. In: Muller, B., Finka, M., Lintz, G. (eds.) Rise and Decline of Indusry in Central and Eastern Europe. A Comperative Study of Cities and Regions in Eleven Countries. Berlin Heidelberg: Springer-Verlag, 131-155.

Paiders, J. (2008). Kvantitatīvu indikatoru izmantošana regionālās attīstības analīzēe: Promocijas darba kopsavilkums. Rīga: Latvijas Universitāte

Peter, M. (2008). Development of Latvia's economy and competitveness after joining the European Union. Norderstedt: GRIN Verlag.

Wu, X., Gao, Y. (2001). Developing Foreign Trade for an Economic Boom. China Today, $50(9), 60$.

\section{Summary}

This article provides an overview of changes and trends in the export of commodities produced by Latvia's primary economic sectors: agriculture, fishing and forestry. A wide range of available statistics and published scientific works are considered.

Statistical analysis of exports utilizes the frequency method and investigates the most stable and constant Latvian export markets. General data were acquired from the Latvian Central Statistics Bureau for the period of 2000 to 2013. The main analytical method was the Fisher $\varphi$ function.

Analysis shows that the most stable Latvian export markets are as follows: the nations of the Baltic Sea Region; Latvia's closest neighbours; and additionally, the Netherlands, Norway and the United Kingdom. Other important markets in and outside Europe were also identified. The applied method allowed for casual markets to be found, where export destination was 
determined by factors other than pure economic gain. End data also confirmed that frequency analysis is viable for utilisation in economic geography research - its application should be deepened and further developed. 